\title{
Low Intensity Laser Irradiation and Growth Factors Influence Differentiation of Adipose Derived Stem Cells into Smooth Muscle Cells in a Coculture Environment over a Period of 72 Hours
}

\author{
Bernard Mvula and Heidi Abrahamse \\ Laser Research Centre, Faculty of Health Sciences, University of Johannesburg, Doornfontein, P.O. Box 17011, Berea, \\ Johannesburg 2028, South Africa \\ Correspondence should be addressed to Heidi Abrahamse; habrahamse@uj.ac.za
}

Received 28 April 2014; Accepted 28 May 2014; Published 17 June 2014

Academic Editor: Gerhard Litscher

Copyright (C) 2014 B. Mvula and H. Abrahamse. This is an open access article distributed under the Creative Commons Attribution License, which permits unrestricted use, distribution, and reproduction in any medium, provided the original work is properly cited.

\begin{abstract}
Stem cells have the ability to self-renew and differentiate into several specialised cells. Low intensity laser irradiation (LILI) has been shown to have positive effects on cells including adipose derived stem cells (ADSCs). Growth factors such as retinoic acid and transforming growth factor (TGF- $\beta 1$ ) play significant roles in the differentiation of cells. This study aimed at investigating the role of LILI and growth factors on differentiation of adipose derived stem cells cocultured with smooth muscle cells (SMCs). The study used isolated human adipose derived stem cells and smooth muscle commercial cells (SKUT-1). The cells were cocultured directly in the ratio $1: 1$ using the established methods with and without growth factors (retinoic acid and TGF- $\beta 1$ ) and then exposed to LILI at a wavelength of $636 \mathrm{~nm}$ with $5 \mathrm{~J} / \mathrm{cm}^{2}$ using a diode laser. The cellular proliferation and expression of the both cell type markers were assessed using optical density and flow cytometry at $24 \mathrm{~h}$ and $72 \mathrm{~h}$. The study showed that LILI increased the proliferation of cocultured cells. The expression of the smooth muscle cell markers increased in the coculture groups that were exposed to LILI in the presence of growth factors while those of the ADSCs decreased.
\end{abstract}

\section{Introduction}

Stem cell treatment is becoming a promising therapy for many degenerative diseases [1]. One source of these cells is adipose tissue [2]. Bone marrow stem cells were commonly used in scientific and clinical applications but, due to their limited number, differentiation potential limits with age [3], and an invasive isolation procedure which may cause complications and death, ADSCs are now the preferred source [4]. Adipose derived stem cells (ADSCs) can be harvested from adipose tissue with ease and in abundance. These cells are easily cultured and maintain their mesenchymal stem cell pluripotency after many passages [5]. ADSCs are able to selfrenew and differentiate into several lineages $[6,7]$. Studies have shown that ADSCs could be differentiated into smooth muscle cells in the presence of the growth factors $[8,9]$. These cells have also been differentiated into adipocytes, osteocytes, and neurons upon exposure to growth factors [10].

Smooth muscle cells form smooth muscle tissues. These tissues are major components of systems like cardiovascular, reproductive, urinary, and intestinal systems. Smooth muscle cells play a major role in diseases like cancer, asthma, arteriosclerosis, and hypertension since they constitute the main layer of smooth muscle tissues $[9,11]$. Gastrointestinal smooth muscle diseases represent a major health problem affecting 2 million individuals every year [12]. Smooth muscle cell regeneration is required in the gastrointestinal tract as defects commonly occur [13].

Low intensity laser irradiation has shown different effects on several biological systems. It induces increased ATP production in mitochondria [14], elevation in collagen production in fibroblasts [15], and muscle regeneration processes 
following injury [16]. LILI has shown to increase viability and proliferation of human fibroblast cells cultured in media with high glucose levels [17]. Cellular viability and proliferation have also been increased in ADSCs when exposed to LILI [18]. It has been shown to improve dental pulp stem cells when cultured in low nutritional conditions [19].

Growth factors are polypeptides that affect a number of cellular processes such as proliferation and differentiation both in vivo and in vitro [20]. Studies on retinoic acid have shown that it has several effects on cells including apoptosis, proliferation, differentiation, and maturation [21, $22]$. Another growth factor, TGF- $\beta 1$, plays a vital role in migration, angiogenesis, differentiation, proliferation, metastasis, and embryonic development $[23,24]$.

Betal integrin (CD29) is a protein that is encoded in humans by ITGB1 gene [25]. It is associated with a late antigen receptor. It is expressed by ADSCs as a cell surface marker [26]. Thymocyte differentiation antigen 1 (Thy-1 CD90) is used as a marker for a variety of mesenchymal stem cells [27]. Both CD29 and CD90 are expressed by ADSCs and have been confirmed as mesenchymal stem cell markers [28]. Myosin heavy chain is a cytoplasmic protein and a major component of SMCs [29]. It is a specific marker for smooth muscle differentiation. The expression of MHC is restricted to smooth muscle tissues [30].

The aim of the study was to investigate the role played by LILI and growth factors on differentiation of ADSCs when cocultured with smooth muscle cells monitored over a period of $72 \mathrm{~h}$.

\section{Materials and Methods}

ADSCs were isolated from adipose tissue voluntarily donated by individuals undergoing abdominoplasty (Academic Ethics approval number 01/06). The isolation was done through collagenase digestion method as described in Mvula et al., 2010 [31]. After isolation, these were cultured in Dulbecco's Modified Eagle Medium (DMEM) (Sigma, D8062, SIgMAAldrich, Kempton Park, SA) with 10\% foetal bovine serum (FBS) (Biochrom, S0615, Biocom biotech, Centurion, SA), $0.1 \%$ penicillin/streptomycin (Sigma, P4333, SIGMA-Aldrich, Kempton Park, SA), and $1 \mu \mathrm{g} / \mathrm{mL}$ fungizone (Sigma, A2942, SIGMA-Aldrich, Kempton Park, SA) incubated at $37^{\circ} \mathrm{C}$ in an atmosphere of $5 \%$ carbon dioxide $\left(\mathrm{CO}_{2}\right)$ in a HERA CELL 150 (Heraeus, 44857, Separation Scientific, Honeydew, SA). A smooth muscle commercial cell line, SKUT-1, purchased from ATCC was also cultured in the same medium with similar conditions as ADSCs.

After reaching semiconfluency for ADSCs and confluency for SKUT-1, both cell types were cocultured directly in $3.4 \mathrm{~cm}^{2}$ diameter dishes in a ratio $1: 1$ with and without the growth factors in MCDB 131 medium (Gibco, 10372019, Life technologies, Roosevelt, SA) with $2 \%$ FBS, $0.1 \%$ penicillin/streptomycin, and $1 \mu \mathrm{g} / \mathrm{mL}$ fungizone incubated at $37^{\circ} \mathrm{C}$ in an atmosphere of $5 \%$ carbon dioxide $\left(\mathrm{CO}_{2}\right)$. The cocultures were divided into 6 groups. Group 1 were cocultures without the growth factors and were not exposed to LILI (CC); group 2 were cocultures without growth
TABLE 1: Laser parameters.

\begin{tabular}{lc}
\hline Wavelength $(\mathrm{nm})$ & 636 \\
Wave emission & Continuous wave \\
Power output $(\mathrm{mW})$ & 85 \\
Spot size $\left(\mathrm{cm}^{2}\right)$ & 9.08 \\
Output density $\left(\mathrm{mW} / \mathrm{cm}^{2}\right)$ & 9.3 \\
Irradiation duration & 9 mins $10 \mathrm{~s}$ \\
Fluence $\left(\mathrm{J} / \mathrm{cm}^{2}\right)$ & 5 \\
\hline
\end{tabular}

factors but were exposed to LILI (CC + LILI); group 3 were cocultures with the growth factor retinoic acid (RA) (Sigma, R2605, Sigma-Aldrich, Kempton Park, SA) and not exposed to LILI $(\mathrm{CC}+\mathrm{RA})$. Group 4 were with RA and exposed to LILI (CC + RA + LILI); group 5 were cocultures with a growth factor, transforming growth factor beta 1 (TGF- $\beta 1$ ) (Invitrogen, PHG 9204, Life technologies, Roosevelt Park, SA) but not exposed to LILI (CC + TGF- $\beta 1$ ) and the last is group 6 which had TGF- $\beta 1$ and were exposed to LILI $(\mathrm{CC}+$ TGF- $\beta 1+$ LILI). RA was added to the cocultures at a concentration of $0.1 \mu \mathrm{M}$ and TGF- $\beta 1$ at $1 \mathrm{ng} / \mathrm{mL}$.

The cocultures of groups 2, 4, and 6 were exposed to diode laser (Oriel, Orroyo Instruments, LTIO00-PLT20, NLC, Pretoria, SA) at $5 \mathrm{~J} / \mathrm{cm}^{2}$ with a wavelength of $636 \mathrm{~nm}$ in the dark. The medium was removed and $1 \mathrm{~mL}$ of Hanks Balanced Salt Solution (HBSS) was added to the plates. Low laser irradiation was then delivered to the plate via the optical fibre as described previously [18, 31]. Cocultures which were not irradiated were used as controls and kept under the same conditions as the irradiated ones. The laser parameters are shown in Table 1.

Proliferation of the cocultures was analysed using optical density (OD) where the absorbance of one hundred microliters of the cell suspension was read at $\mathrm{A}_{540} \mathrm{~nm}$ in a Perkin Elmer, Victor ${ }^{3}$ (Perkin Elmer, 1420, Separation Scientific, Honeydew, SA).

Cocultures were rinsed three times with Hanks Balanced Salt Saline (HBSS) (SIGMA, H9394, Sigma-Aldrich, Kempton Park, SA). The cells were then removed from the small plates by adding $500 \mu \mathrm{L}$ of Triple Express (Life technologies 1260-028) and incubated at $37^{\circ} \mathrm{C}$ for $5 \mathrm{~min}$. The cells were then washed in HBSS once and twice in PBS/BSA/azide. Antihuman CD29 ( $\beta 1$ integrin), antimouse CD90 (Thy-1), and antihuman myosin heavy chain (MHC) were then added and incubated for $30 \mathrm{~min}$ on ice. The cells were washed three times with PBS/BSA/azide and then fixed for $10 \mathrm{~min}$ in 3.7\% formalin. Permeability was done by incubating the cell suspension in $1 \%$ triton $\mathrm{x}-100$. The suspension was washed twice and the pellet was suspended in PBS, ready for reading with the BD FacsAria ${ }^{\mathrm{TM} 111}$ machine (BD Biosciences, 22300099, Scientific Group Biosciences, Woodmead, SA).

Sigma plot 11.0 software was used to analyse all experiments which were performed 6 times and assays in duplicates. Determination of the differences between the groups for each independent variable was done by using Student's $t$-test. Statistical significances comparing the groups are shown as 

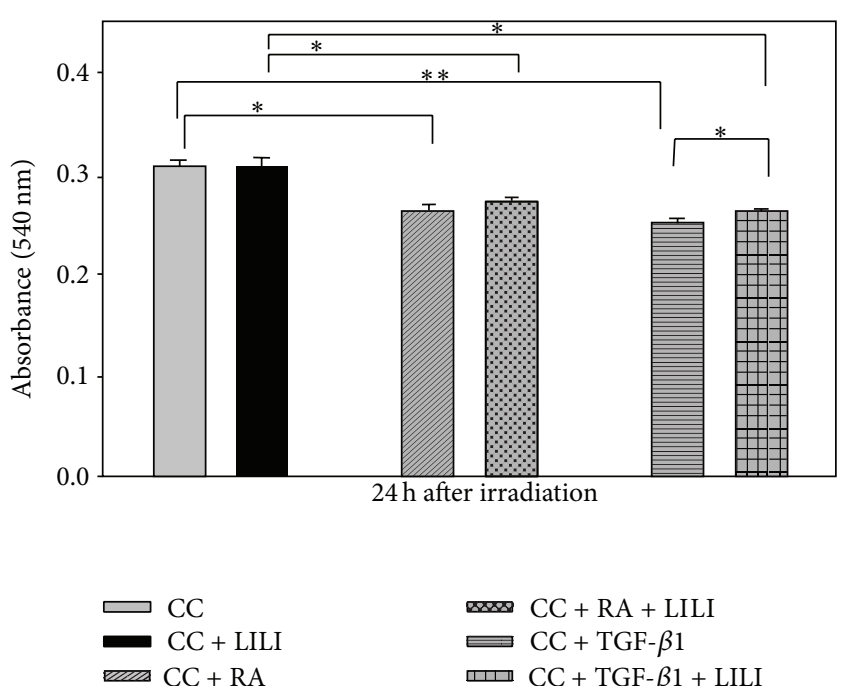

$$
\begin{aligned}
& \omega \mathrm{CC}+\mathrm{RA}+\mathrm{LILI} \\
& \text { ”CC + TGF- } \beta 1 \\
& \text { ए CC + TGF- } \beta 1+\text { LILI }
\end{aligned}
$$

FIGURE 1: Cellular proliferation as assessed by optical density at $24 \mathrm{~h}$ after irradiation. Groups that were irradiated increased in proliferation as compared to those that were not exposed to irradiation. A decrease in proliferation was observed in groups that had growth factors as compared to those without growth factors.

star ${ }^{*}$, where $P<0.05\left({ }^{*}\right), P<0.01\left(^{* *}\right)$, and $P<0.001\left({ }^{* * *}\right)$ in the table and figures.

\section{Results}

The optical density results which measured cellular proliferation showed increases in cocultures that were irradiated as compared to their respective control groups and this was significantly observed in the groups that had TGF- $\beta 1$ growth factor at $24 \mathrm{~h}(P<0.05)$. The cocultures which were grown in the presence of growth factors had decreases in cellular proliferation. At $24 \mathrm{~h}$, the proliferation significantly decreased in cocultures that were grown in the presence of RA and TGF$\beta 1$ as compared to those without growth factors (CC and CC + LILI) as seen in Figure 1.

Proliferation of the cells, as observed through optical density analysis at $72 \mathrm{~h}$, showed a similar trend to that at $24 \mathrm{~h}$. The cocultures that were grown in the presence of growth factors decreased in proliferation as compared to the cocultures that had no growth factors. The decrease was significant in groups with RA and TGF- $\beta 1$ as compared to the groups without growth factors (CC and CC + LILI). The groups that were irradiated increased in proliferation compared to those that were not irradiated and this was significant in groups 1, 2, 3, 4, 5, and 6 (Figure 2).

The expression of the markers for both ADSCs (CD29 and CD90) and SMCs (MHC) was analysed through flow cytometry. CD29 expression decreased in the cocultures that were grown in the presence of growth factors at both $24 \mathrm{~h}$ and $72 \mathrm{~h}$ and the decrease was significant $(P<0.05)$ in the cocultures that had TGF- $\beta 1$ and were irradiated (CC + TGF- $\beta 1+$ LILI) at $72 \mathrm{~h}$ as compared to the control group (CC). At both $24 \mathrm{~h}$ and $72 \mathrm{~h}, \mathrm{CD} 90$ expression decreased

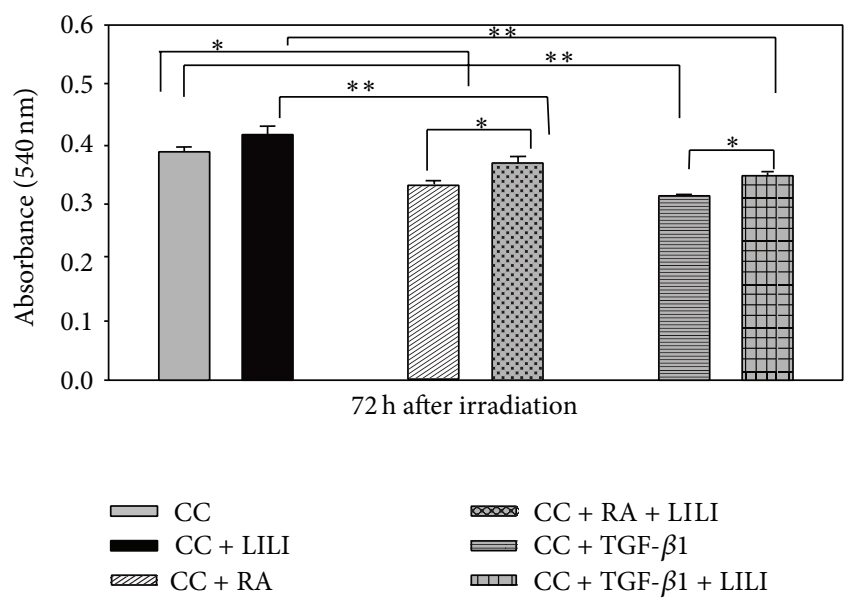

Figure 2: Cellular proliferation as assessed by optical density at $72 \mathrm{~h}$ after irradiation. Groups that were irradiated increased in proliferation as compared to those that were not exposed to irradiation but there was a decrease in the groups with growth factors as compared to those without growth factors.

statistically significant in the cocultures that had TGF- $\beta 1$ and were irradiated (CC + TGF- $\beta 1$ and CC + TGF- $\beta 1+$ LILI) as compared to the control group (CC) at $72 \mathrm{~h}$ with $P$ values of less than 0.05 and 0.001 , respectively. SMC marker, myosin heavy chain, showed an increase in the cocultures at $72 \mathrm{~h}$ though the increase was not statistically significant (Table 2). However, this may change if the expression of markers was followed for an additional extended period.

\section{Discussion}

Stem cells could be used for treatment of several diseases such as Parkinson's, stroke, diabetes, traumatic injury, and multiple sclerosis diseases. These diseases are caused by either loss or damage of the cells in the organs or tissues [32]. Stem cells have to be differentiated into cells which are required to repair or replace the lost or damaged cells. ADSCs have been shown to have a high plasticity capability. They have been able to differentiate into smooth muscle, neuron, bone, cartilage, and fat cells $[9,33]$. Differentiating ADSCs into SMCs would assist in the treatment of diseases that affect diseases in the cardiovascular, intestinal, urinary, and reproductive systems $[11,34]$.

Studies on coculturing of cells have proved that differentiation can be increased due to the secretion of growth factors of the cells that will be differentiated into. Previous studies have shown that LILI can increase cell viability and proliferation $[18,25]$. Growth factors have shown to have many effects on cells that include proliferation and differentiation and they play major roles in these processes [20-24]. The results in the present study showed a decrease in the proliferation of ADSCs and an increase in the proliferation of SMCs. This was observed through flow cytometry analysis; however, this could not be distinguished in the optical density analysis of the cocultures. 
TABLE 2: Flow cytometric results for the expression of the markers for both ADSCs and SKUT-1 cells. CD29 and Thy-1 expressions decreased significantly at $72 \mathrm{~h}$ in cocultures that had TGF- $\beta 1$ and were irradiated at $72 \mathrm{~h} .{ }^{*} \mathrm{P}<0.05$ and ${ }^{* *} \mathrm{P}<0.01$.

\begin{tabular}{|c|c|c|c|c|c|c|}
\hline & $\mathrm{CC}$ & CC + LILI & $\mathrm{CC}+\mathrm{RA}$ & $\mathrm{CC}+\mathrm{RA}+\mathrm{LILI}$ & $\mathrm{CC}+\mathrm{TGF}-\beta 1$ & CC + TGF- $\beta 1+$ LILI \\
\hline \multicolumn{7}{|c|}{ CD29 ( $\beta 1$ integrin $)$} \\
\hline $24 \mathrm{~h}$ & 58.93 & 59.70 & 59.70 & 61.00 & 69.40 & 53.18 \\
\hline $72 \mathrm{~h}$ & 49.25 & 50.50 & 42.75 & 41.25 & 42.50 & $38.00^{*}$ \\
\hline \multicolumn{7}{|c|}{ CD90 (Thy-1) } \\
\hline $24 \mathrm{~h}$ & 56.23 & 61.75 & 52.85 & 56.00 & 54.05 & 55.10 \\
\hline $72 \mathrm{~h}$ & 43.00 & 45.75 & 39.75 & 35.75 & $31.25^{*}$ & $24.50^{* *}$ \\
\hline \multicolumn{7}{|c|}{ Myosin heavy chain } \\
\hline $24 \mathrm{~h}$ & 71.70 & 73.25 & 69.18 & 68.63 & 65.73 & 67.85 \\
\hline $72 \mathrm{~h}$ & 72.53 & 78.50 & 76.38 & 81.20 & 73.23 & 80.55 \\
\hline
\end{tabular}

In this study LILI increased the proliferation of cocultured cells; however, in the cocultures that had growth factors, proliferation decreased as compared to the cocultures without growth factors. This could have been due to the fact that proliferation of ADSCs was halted while differentiation into SMCs was initiated. Flow cytometry results concurred with this observation since a decrease in expression of the ADSCs markers in the cocultures was observed while those of the SMCs increased. This once again supports the argument that proliferation was inhibited since ADSCs were preparing for differentiation.

\section{Conclusion}

This study, in agreement with other studies done previously, found that LILI increases cell proliferation. LILI in combination with growth factors could differentiate ADSCs into SMCs. The study recommends that further investigations, especially, analysing the regulation of different genes involved in the differentiation of ADSCs into SMCs, are necessary to confirm differentiation. Once differentiation is confirmed, LILI and growth factors, such as RA and TGF- $\beta 1$, would play major roles in the established direct coculturing method for the differentiation of stem cells into SMCs and this would be very beneficial in the stem cell therapy for many degenerative diseases which involves smooth muscle cells. However, significant further research and investigation are required to realise the clinical potential for cell therapy of ADSC differentiation into SMCs and the contributory role that LILI may have in this process.

\section{Conflict of Interests}

There is no conflict of interests regarding the publication of this paper.

\section{Acknowledgments}

This project was supported by the University of Johannesburg, National Laser Centre, and National Commission for Science and Technology (Malawi). The material in this review paper prepared for International Journal of Photoenergy neither has been published nor is being considered elsewhere for publication.

\section{References}

[1] M. F. Taha, "Cell based-gene delivery approaches for the treatment of spinal cord injury and neurodegenerative disorders," Current Stem Cell Research and Therapy, vol. 5, no. 1, pp. 23-36, 2010.

[2] H. Nakagami, R. Morishita, K. Maeda, Y. Kikuchi, T. Ogihara, and Y. Kaneda, "Adipose tissue-derived stromal cells as a novel option for regenerative cell therapy," Journal of Atherosclerosis and Thrombosis, vol. 13, no. 2, pp. 77-81, 2006.

[3] S. M. Mueller and J. Glowacki, "Age-related decline in the osteogenic potential of human bone marrow cells cultured in three-dimensional collagen sponges," Journal of Cellular Biochemistry, vol. 82, no. 4, pp. 583-590, 2001.

[4] S. Y. Lee, M. Miwa, Y. Sakai et al., "In vitro multipotentiality and characterization of human unfractured traumatic hemarthrosis-derived progenitor cells: a potential cell source for tissue repair," Journal of Cellular Physiology, vol. 210, no. 3, pp. 561-566, 2007.

[5] P. A. Zuk, M. Zhu, P. Ashjian et al., "Human adipose tissue is a source of multipotent stem cells," Molecular Biology of the Cell, vol. 13, no. 12, pp. 4279-4295, 2002.

[6] S. Jang, H.-H. Cho, Y.-B. Cho, J.-S. Park, and H.-S. Jeong, "Functional neural differentiation of human adipose tissuederived stem cells using bFGF and forskolin," BMC Cell Biology, vol. 11, article no. 25, 2010.

[7] T. Huang, D. He, G. Kleiner, and J. Kuluz, "Neuron-like differentiation of adipose-derived stem cells from infant piglets in vitro," Journal of Spinal Cord Medicine, vol. 30, no. 1, pp. S35S40, 2007.

[8] J. A. de Villiers, N. N. Houreld, and H. Abrahamse, "Influence of low intensity laser irradiation on isolated human adipose derived stem cells over $72 \mathrm{hrs}$ and their differentiation potential into smooth muscle cells using retinoic acid," Stem Cell Reviews and Reports, vol. 7, no. 4, pp. 869-882, 2011.

[9] L. V. Rodríguez, Z. Alfonso, R. Zhang, J. Leung, B. Wu, and L. J. Ignarro, "Clonogenic multipotent stem cells in human adipose tissue differentiate into functional smooth muscle cells," Proceedings of the National Academy of Sciences of the United States of America, vol. 103, no. 32, pp. 12167-12172, 2006.

[10] L. Hu, J. Hu, J. Zhao et al., "Side-by-side comparison of the biological characteristics of human umbilical cord and adipose 
tissue-derived mesenchymal stem cells," BioMed Research International, vol. 2013, Article ID 438243, 12 pages, 2013.

[11] S. Sinha, B. R. Wamhoff, M. H. Hoofnagle et al., "Assessment of contractility of purified smooth muscle cells derived from embryonic stem cells," Stem Cells, vol. 24, no. 7, pp. 1678-1688, 2006.

[12] V. Gabetta, W. Trzyna, C. Phiel, and K. M. McHugh, "Vesicleassociated protein-A is differentially expressed during intestinal smooth muscle cell differentiation," Developmental Dynamics, vol. 228, no. 1, pp. 11-20, 2003.

[13] K. M. McHugh, "Molecular analysis of gastrointestinal smooth muscle development," Journal of Pediatric Gastroenterology and Nutrition, vol. 23, no. 4, pp. 379-394, 1996.

[14] S. Passarella, E. Casamassima, S. Molinari et al., "Increase of proton electrochemical potential and ATP synthesis in rat liver mitochondria irradiated in vitro by helium-neon laser," FEBS Letters, vol. 175, no. 1, pp. 95-99, 1984.

[15] I. B. Kovacs, E. Mester, and P. Gorog, "Stimulation of wound healing with laser beam in the rat," Experientia, vol. 30, no. 11, pp. 1275-1276, 1974.

[16] A. C. Amaral, N. A. Parizotto, and T. F. Salvini, "Dosedependency of low-energy HeNe laser effect in regeneration of skeletal muscle in mice," Lasers in Medical Science, vol. 16, no. 1, pp. 44-51, 2001.

[17] M. Esmaeelinejad, M. Bayat, H. Darbandi, M. Bayat, and N. Mosaffa, "The effects of low-level laser irradiation on cellular viability and proliferation of human skin fibroblasts cultured in high glucose mediums," Lasers in Medical Science, vol. 29, no. 1, pp. 121-129, 2014.

[18] B. Mvula, T. Mathope, T. Moore, and H. Abrahamse, "The effect of low level laser irradiation on adult human adipose derived stem cells," Lasers in Medical Science, vol. 23, no. 3, pp. 277-282, 2008.

[19] F. D. P. Eduarde, D. F. Bueno, P. M. De Freitas et al., "Stem cell proliferation under low intensity laser irradiation: a preliminary study," Lasers in Surgery and Medicine, vol. 40, no. 6, pp. 433438, 2008.

[20] A. S. Goustin, E. B. Leof, G. D. Shipley, and H. L. Moses, "Growth factors and cancer," Cancer Research, vol. 46, no. 3, pp. 1015-1029, 1986.

[21] V. Duong and C. Rochette-Egly, "The molecular physiology of nuclear retinoic acid receptors. From health to disease," Biochimica et Biophysica Acta, vol. 1812, no. 8, pp. 1023-1031, 2011.

[22] L. J. Gudas and J. A. Wagner, "Retinoids regulate stem cell differentiation," Journal of Cellular Physiology, vol. 226, no. 2, pp. 322-330, 2011.

[23] R. Zhang, G. S. Jack, N. Rao et al., "Nuclear fusion-independent smooth muscle differentiation of human adipose-derived stem cells induced by a smooth muscle environment," Stem Cells, vol. 30, no. 3, pp. 481-490, 2012.

[24] R. A. Rahimi and E. B. Leof, "TGF- $\beta$ signaling: a tale of two responses," Journal of Cellular Biochemistry, vol. 102, no. 3, pp. 593-608, 2007.

[25] P. J. Goodfellow, H. A. Nevanlinna, P. Gorman, D. Sheer, G. Lam, and P. N. Goodfellow, "Assignment of the gene encoding the beta-subunit of the human fibronectin receptor ( $\beta$-FNR) to chromosome 10p11.2," Annals of Human Genetics, vol. 53, no. 1, pp. 15-22, 1989.

[26] K. Yoshimura, T. Shigeura, D. Matsumoto et al., "Characterization of freshly isolated and cultured cells derived from the fatty and fluid portions of liposuction aspirates," Journal of Cellular Physiology, vol. 208, no. 1, pp. 64-76, 2006.

[27] N. M. Masson, I. S. Currie, J. D. Terrace, O. J. Garden, R. W. Parks, and J. A. Ross, "Hepatic progenitor cells in human fetal liver express the oval cell marker Thy-1," American Journal of Physiology, vol. 291, no. 1, pp. G45-G54, 2006.

[28] F. Zahran, M. Salam, A. Loffy, and I. M. El-Deen, "Isolation and characterisation of adipose tissue-derived stem cells: an in vitro study," Basic Research Journal of Medicine and Clinical Sciences, vol. 1, no. 5, pp. 88-94, 2012.

[29] M. M. Nicolas, P. Tamboli, J. A. Gomez, and B. A. Czerniak, "Pleomorphic and dedifferentiated leiomyosarcoma: clinicopathologic and immunohistochemical study of 41 cases," Human Pathology, vol. 41, no. 5, pp. 663-671, 2010.

[30] M. Aikawa, Y. Sakomura, M. Ueda et al., "Redifferentiation of smooth muscle cells after coronary angioplasty determined via myosin heavy chain expression," Circulation, vol. 96, no. 1, pp. 82-90, 1997.

[31] B. Mvula, T. J. Moore, and H. Abrahamse, "Effect of low-level laser irradiation and epidermal growth factor on adult human adipose-derived stem cells," Lasers in Medical Science, vol. 25, no. 1, pp. 33-39, 2010.

[32] K. M. Safford and H. E. Rice, "Stem cell therapy for neurologic disorders: therapeutic potential of adipose-derived stem cells," Current Drug Targets, vol. 6, no. 1, pp. 57-62, 2005.

[33] N. Serakinci and W. N. Keith, "Therapeutic potential of adult stem cells," European Journal of Cancer, vol. 42, no. 9, pp. 12431246, 2006.

[34] P. Carmeliet, "Mechanisms of angiogenesis and arteriogenesis," Nature Medicine, vol. 6, no. 4, pp. 389-395, 2000. 

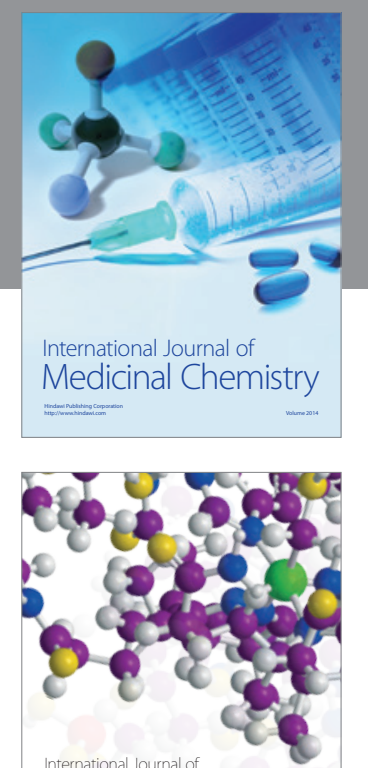

\section{Carbohydrate} Chemistry

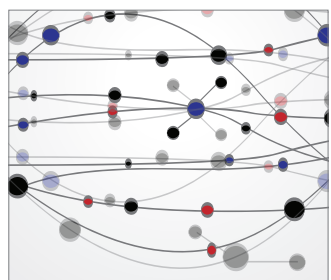

The Scientific World Journal
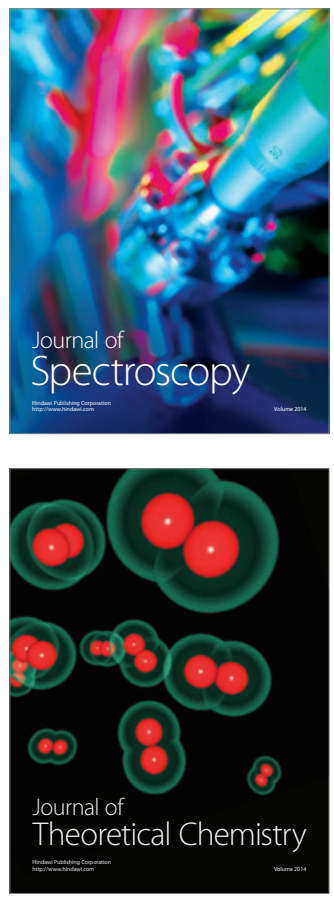
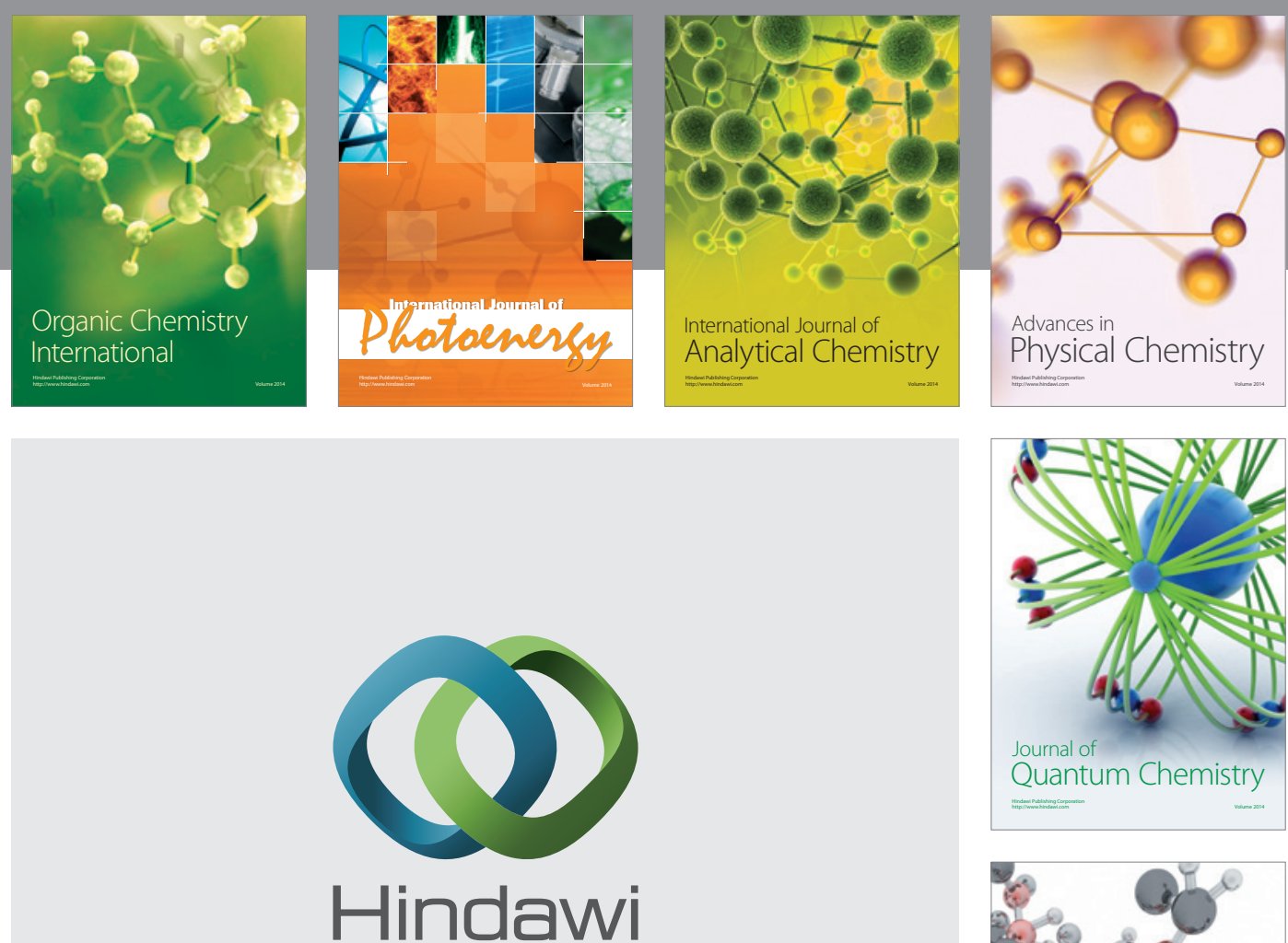

Submit your manuscripts at

http://www.hindawi.com

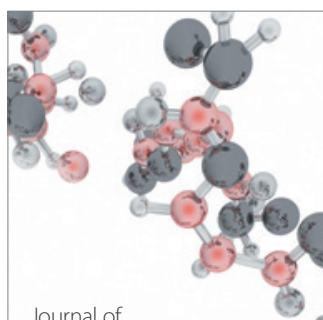

Analytical Methods

in Chemistry

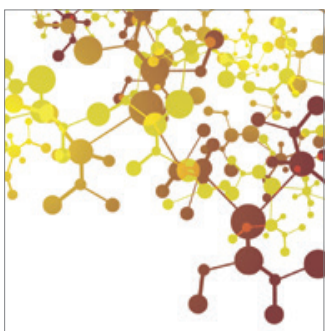

Journal of

Applied Chemistry



Inorganic Chemistry
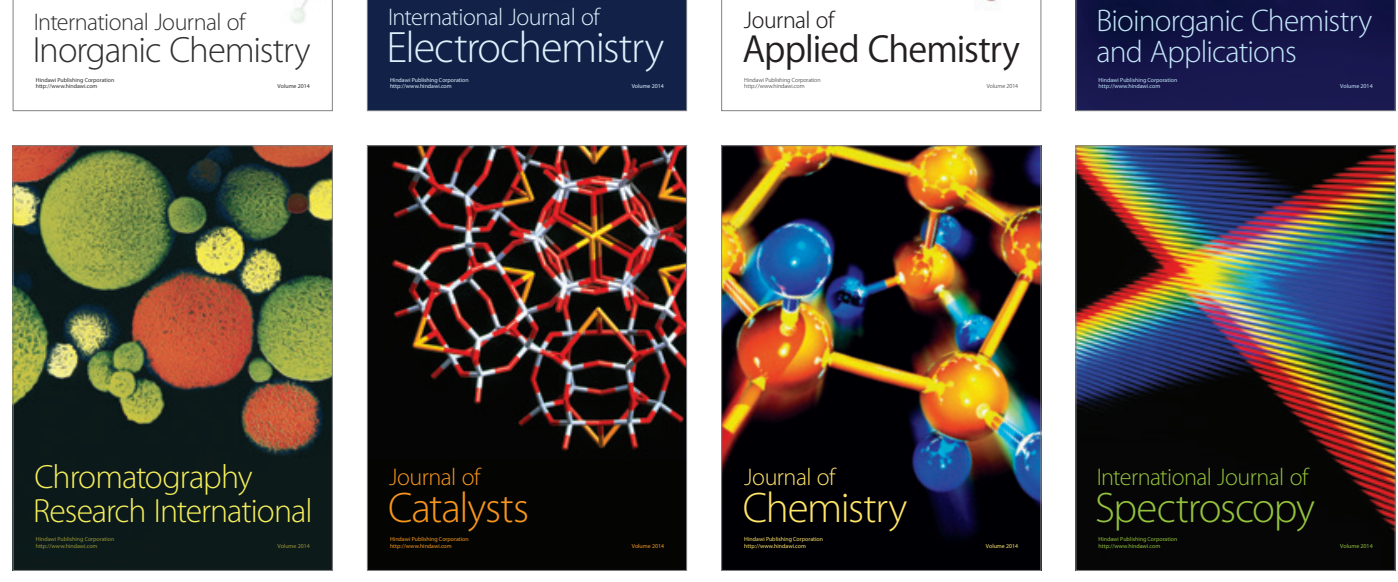